\section{ЛІНГВІСТИЧНИЙ СУПРОВІД МІЖНАРОДНОЇ дІяльності}

\section{Білецька Оксана Олександрівна}

кандидат культурології, доцент,

Київський національний університет культури і мистецтв,

м. Київ, Україна

ORCID: 0000-0003-1785-9607

bel_o@ukr.net
Надіслано:

14.06.2020

Рецензовано:

30.06 .2020

Прийнято:

10.07.2020

Трансформація міжнародних процесів і явищ, модернізаційні політичні процеси, глобалізація всього суспільного життя, пріоритетність зовнішньополітичної діяльності задля просування інтересів як України, так і інших держав у світі, інноваційність інструментарію міжнародної взаємодії обумовлюють актуалізацію вивчення значення умінь і навичок іншомовної комунікації та перекладу фахівців-міжнародників, що спрямовані на забезпечення міжнародної взаємодії та формування тривалих формальних і неформальних зв'язків між урядовими інститутами, міжнародними акторами, дипломатичними установами й політичними лідерами 3 метою реалізації політичних, економічних, безпекових, культурних, соціальних і гуманітарних ініціатив і проєктів, а також з метою удосконалення процесів управління установами як внутрішньої, так і зовнішньої координації, покращення іміджу країн на міжнародній арені. Мета статті полягає у дослідженні ролі вмінь здійснення іншомовної комунікації та перекладу, їх значення у реалізації та здійсненні зовнішньополітичної діяльності. Методологія дослідження $\epsilon$ комплексною і визначається специфікою предмета дослідження, його метою і завданнями, а також міждисциплінарним підходом до визначеної проблеми. у результаті зроблено висновки, що професійна діяльність фахівців 3 міжнародних відносин, дипломатів, міжнародних акторів $\epsilon$ сферою міжнародної комунікації, що включає політику, проблеми та події суспільного і державного життя, а мови, якими розмовляють в різних країнах, вимагають рішень для подолання лінгвістичного розриву.

Ключові слова: лінгвістичний супровід; дипломатія; міжнародні відносини; зовнішньополітична діяльність; фахівці; комунікація; офіційні і робочі мови. 
Biletska Oksana, Candidate of Cultural Studies, Associate Professor, Kyiv National University of Culture and Arts, Kyiv, Ukraine

\section{Linguistic Support of the International Activity}

International processes and phenomena transformation, political processes modernization, globalization of all public life, the priority of foreign policy activities to promote both Ukraine and other countries' interests in the world, and the innovativeness of the international interaction tools determine the actualization of the study of the international specialists' of skills and knowledge of foreign language communication and translation importance, aimed at ensuring international interaction and the formation of long-term formal and informal ties between government institutions, international actors, diplomatic institutions and political leaders in order to implement political, economic, security, cultural, social and humanitarian initiatives and projects, as well as to improve the management processes of institutions, both internal and external coordination, improving the state's image in the international arena. The purpose of the article is to study the role of foreign language communication and translation skills and their importance in implementing foreign policy. The research methodology is complex. It is determined by the specifics of the subject of research, its purpose and objectives, as well as an interdisciplinary approach to the research problem. The study concluded that the professional activities of international relations specialists, diplomats, and international actors are a field of international communication, including policies, problems and events of public and state life, and languages spoken in different countries require solutions to bridge the linguistic gap, arising in the implementation of external international relations.

Key words: linguistic support; diplomacy; international relations; foreign policy activities; specialists; communication; official and working languages.

Белецкая Оксана Александровна, кандидат культурологии, доцент, Киевский национальный университет культуры и искусств, г. Киев, Украина

\section{Лингвистическое сопровождение международной деятельности}

Трансформация международных процессов и явлений, модернизационные политические процессы, глобализация всей общественной жизни, приоритетность внешнеполитической деятельности для продвижения интересов как Украины, так и других государств в мире, инновационность инструментария международного взаимодействия обусловливают актуализацию изучения значения умений и навыков иноязычной коммуникации и перевода специалистов-международников, направленные на обеспечение международного взаимодействия и формирование длительных формальных и неформальных связей между правительственными институтами, международными актерами, дипломатическими учреждениями и 
политическими лидерами с целью реализации политических, экономических, безопасности, культурных, социальных и гуманитарных инициатив и проектов, а также с целью усовершенствования процессов управления учреждениями как внутренней, так и внешней координации, улучшение имиджа стран на международной арене. Цель статьи заключается в исследовании роли иноязычной коммуникации и перевода, а так же и их значение в реализации и осуществлении внешнеполитической деятельности. Методология исследования является комплексной и определяется спецификой предмета исследования, его целью и задачами, а также междисциплинарным подходом к исследуемой проблеме. В результате исследования сделаны выводы, что профессиональная деятельность специалистов по международным отношениям, дипломатов, международных акторов является сферой международной коммуникации, включая политику, проблемы и события общественной и государственной жизни, а языки, на которых говорят в разных странах, требуют решений для преодоления лингвистического разрыва, возникающие при осуществлении внешних международных отношений.

Ключевые слова: лингвистическое сопровождение; дипломатия; международные отношения; внешнеполитическая деятельность; специалисты; коммуникация; официальные и рабочие языки.

\section{Вступ}

Механізми глобалізації та ï наслідки стали об'єктом грунтовних досліджень, дискусій і суперечок серед багатьох науковців. Проте сучасні міжнародні відносини все більше охоплюють нові сфери спілкування, у тому числі в тих галузях, що традиційно вважалися внутрішньо національними, тому традиційні підходи і предметна модель підготовки майбутніх фахівців з міжнародних відносин не повністю відображають потреби реальної практики їх професійної діяльності.

Якість підготовки міжнародників $є$ великою мірою питанням безпеки, ефективності політико-економічного та соціокультурного розвитку країни. Однією 3 перешкод при здійсненні їх професійної діяльності в мультикультурному просторі стає недостатня мовно-фахова підготовка, що призводить, щонайменше, до непорозуміння, виникнення конфліктних ситуацій, а у крайньому випадку - до зниження темпів співпраці, збільшення терміну виконання контрактів, зриву договорів тощо.

\section{Аналіз попередніх досліджень та публікацій}

Аналіз літератури щодо питання, пов'язаного 3 іншомовною комунікацією фахівців-міжнародників, показує, що воно завжди перебуває у стадії активного обговорення: питання організації навчання на основі теоретичних положень міжкультурної комунікації (B. D. Müller, Н. Д. Гальскова, 
В. В. Сафонова, В. П. Фурманова, I. І. Халеєва), роль тексту як джерела інформації про культуру країни, мова якої опановується, в системі підготовки фахівцівміжнародників та працівників дипломатичної служби (D. Keppler, S. Nick, R. Cohen) тощо. У свою чергу, останнім часом активізувалися дослідження щодо іншомовних комунікацій та перекладу, їх ролі в історії, принципах та засадах використання у світових міжнародних відносинах, ролі лінгвістичного супроводу та перекладу в здійсненні сучасної дипломатичної практики (О. Сніговська, А. Мілкова, Т. Barabyai, T. Osborne, S. H. Shubbar, Dr. M. Ib. Nasir, J. Delisle). Професійну мовну підготовку, в тому числі дипломатів та міжнародників-перекладачів, в історичному аспекті представлено в роботах А. Арсеньєва, М. Баркової, С. Бєлокурова, О. Воєводи, Д. Латишіної тощо.

\section{Формулювання цілей статті}

Метою дослідження $\epsilon$ окреслення ролі іншомовної комунікативної компетентності як у контексті європейського вектора підготовки сучасних дипломатичних кадрів, так і у системі професійної діяльності фахівців 3 міжнародних відносин. Адже здатність таких спеціалістів до спілкування та співпраці з людьми різних культур під час реалізації міжнародної діяльності, а також як у дво- так і/або багатосторонніх дипломатичних відносинах набуває надзвичайного значення. I це $є$ одним 3 головних завдань, оскільки саме достатній рівень іншомовної комунікативної компетенції дозволить фахівцюміжнароднику належним чином виконувати свої професійні обов'язки і розв'язувати ситуації, що виникають під час виконання професійних обов'язків в іноземній країні.

\section{Виклад основного матеріалу дослідження}

Людство вирішує проблеми комунікації вже протягом багатьох тисячоліть. Ці проблеми супроводжують людину з його перших кроків, і вирішуються нею швидше або повільніше на різних етапах розвитку людської культури та взаємин між людьми. Історично склалося так, що людство не має однієї спільної мови. Але людина не може існувати ізольовано. 3 найдавніших часів, люди намагалися встановлювати контакти між собою. Так, перші посланці єгипетських фараонів, римські легати, середньовічні консули Дубровницької республіки тощо мали бути добре освіченими та професійно підготовленими людьми, володіти мистецтвом красномовства та бути поліглотами (Mehtiyev, 2010).

Явище міжнародних відносин виникло на ранніх етапах історії людства і протягом історичного розвитку людської цивілізації зазнало значної еволюції. На рубежі II і III тисячоліть, внаслідок глобалізації світового співтовариства, коли сучасні країни перебувають у стані різноманітних і багатогранних взаємодій, значення міжнародних відносин суттєво зросло, в результаті чого міжнародні комунікації набули статусу найважливішого інструменту 
формування та підтримки міжнародних відносин. Наразі одна з провідних ролей у сучасному світі відводиться таким процесам людської діяльності, що пов'язані 3 певними контактами між соціальними групами різних країн, тобто з міжнародними відносинами в широкому сенсі слова.

У реалізації таких контактів - спілкуванню на міжнародному рівні в першу чергу беруть участь чиновники та фахівці з усного та письмового перекладів, тим самим формуючи команду для організації та підтримки плідних міжнародних відносин.

Крім поняття «міжнародні відносини» широко вживається і таке поняття як «зовнішня політика». Кожна політична одиниця, тобто держава, в межах своїх можливостей, економічних, соціальних та етнічних особливостей визначає для себе тактичні та стратегічні зовнішньополітичні цілі. Діяльність, спрямована на реалізацію цих цілей, і являє собою суть «зовнішньої політики». Таким чином, зовнішня політика - це система дій міжнародного актора, спрямована на забезпечення впливу на поведінку інших суб'єктів міжнародних відносин та пристосування до наслідків процесів міжнародної системи (Vydy ta formy mizhnarodnykh vidnosyn). Також можна зазначити, що зовнішня політикаце діяльність держави на міжнародній арені, яка регулює відносини з іншими суб'єктами зовнішньополітичної діяльності: державами, зарубіжними партіями та іншими громадськими, всесвітніми i регіональними міжнародними організаціями.

У свою чергу, дипломатія як мистецтво «здійснення міжнародних відносин шляхом переговорів; сукупність засобів, що їх використовують посли й посланці з метою забезпечення переговорного процесу; праця або мистецтво дипломата» $є$ формальним способом спілкування між державами (Diplomacy). Оскільки в більшості випадків різні держави навіть у межах однієї країни використовують декілька мов, то забезпечення міжнародних комунікацій зазвичай потребує використання спільної мови, задля уникнення будь-яких непорозумінь на міждержавному рівнях. Таку спільну мову, що використовується в дипломатичних цілях, іноді називають «дипломатичною мовою». Нині термін «дипломатична мова» використовують для позначення трьох різних понять. У своєму першому значенні воно означає фактичну мову (іспанську, французьку і англійську), якою послуговуються дипломати в листуванні, або перемовинах. Друге значення цього терміна стосується сукупності слів і виразів, які є ядром дипломатичного вокабуляру. У своєму третьому, і найбільш поширеному сенсі цей термін використовують, щоб описати мову, яка дозволяє дипломатам висловлювати складні, або потенційно суперечливі ідеї у ввічливій формі (Kashchyshyn, 2017).

Питання вибору мови для забезпечення та здійснення міждержавних відносин завжди турбувало дипломатів, і за різних історичних часів офіційні 
мови були різними, що пояснюється послабленням чи посиленням впливу держави на міжнародній арені. Однак, англійська мова завжди залишалася пріоритетною у світовій дипломатії, за використанням посідаючи перше місце як серед загального люду, так і представників елітних прошарків суспільства. Окрім 375 мільйонів носіїв англійської мови, близько 1,1 мільярда людей у світі володіють англійською як другою чи іноземною мовою. 51 \% населення Європи говорить англійською як рідною чи іноземною мовою. Тому, будучи гнучкою щодо мовних варіацій, англійська мова у глобальному значенні набула статусу «мови влади та престижності», а отже, стала міжнародною запорукою соціального та економічного прогресу. Сучасне панування англійської як світової мови є безперечним, адже вона має статус офіційної або робочої у більшості міжнародних організацій (Mehtiyev, 2010).

Очевидно, що зростаюча демократизація міжнародних відносин призводить, серед іншого, до постійного збільшення кількості мов, що використовуються у сфері багатосторонньої дипломатії, що подекуди ще більше ускладнює спілкування, не завжди відбувається адекватно, й інколи стає досить дорогим явищем. Намагаючись у власний спосіб вирішити лінгвістичну проблему, різні міжнародні організації та організатори численних дипломатичних конференцій вдаються до послуг перекладачів (послуги синхронного перекладу на конференціях та перекладу величезної кількості письмових матеріалів для міжнародних організацій), втім намагаючись звузити їх роботу до відносно невеликої кількості мов - офіційних або робочих.

Звичайно, окрім англійської та французької, в наші дні в дипломатичних цілях використовується ряд інших мов, особливо в якості робочих, наприклад, у міжнародних організаціях, які беруть на себе функції реалізації багатосторонньої дипломатичної діяльність, оскільки ці міжнародні організації включають ряд держав-членів. Як приклад такого багатостороннього співробітництва можна згадати Дунайську комісію, робочими мовами якої є французька, німецька та російська мови. Іншим прикладом може бути Організація країн-експортерів нафти (ОПЕК), яка використовує арабську, англійську та іспанську мови в якості робочих мов. На зустрічах високого рівня позаблокових країн використовується арабська, англійська, французька та іспанська мови (Nick, 2001, pp.46-47). В Організації Об'єднаних Націй, крім двох раніше згаданих мов, також офіційними мовами вважаються арабська, китайська, російська та іспанська; проте на пленарних засіданнях учасники мають вибір навіть використовувати рідну мову. У цьому випадку, звичайно, переклад виступу повинен бути забезпечений хоча б однією з робочих мов організації.

Домінуюча роль тієї чи іншої мови в дипломатії та міжнародній діяльності зумовлена політичним, стратегічним, економічним, культурним чи 
іншим домінуванням тієї чи іншої держави на міжнародній арені. Якщо розглянути мовні вимоги до дипломатів до постійних представництв Ради Європи, то стає очевидним, що насамперед потрібно на високому рівні володіти французькою мовою, оскільки їх професійна діяльність орієнтована на соціальні кола, пресу, консульську роботу чи культурне життя. Якщо дипломат хоче вільно спілкуватися 3 іншими повноважними представниками інших держав, йому, в першу чергу, знадобиться англійська, а, можливо, стане у нагоді й володіння німецькою та російською мовами (залежно від підрозділів дипломатичного корпусу).

У свою чергу, використання мови в письмовому дипломатичному спілкуванні, як правило, $є$ чітко визначеною (найчастіше за двосторонньою домовленістю країн). Загалом, вибір мови міжнародного спілкування базується на одному з фундаментальних принципів сучасного міжнародного права принципі суверенної рівності держав. Наразі існує кілька формул у застосуванні цього принципу по відношенню до лінгвістичного питання, кожна 3 яких реалізується симетрично (Mehtiyev, 2010):

а) кожна сторона здійснює кореспонденцію (ноти, листи тощо) своєю мовою (наприклад, хорватське міністерство в Загребі, а також посольство Хорватії в Будапешті, пишуть хорватською мовою, тоді як міністерство Угорщини та їх посольство в Загребі здійснюють письмові комунікації угорською мовою);

б) кожна сторона листується мовою іншої сторони (протилежне практиці a);

в) листування в кожній країні ведеться місцевою мовою (наприклад, обидві сторони в Загребі ведуть листування хорватською, а в Будапешті угорською);

г) обидві сторони використовують третю, взаємоузгоджену мову наприклад, російську, французьку тощо.

Іншим проблемним, проте добре відомим усім дипломатам та/чи фахівцям-міжнародникам, що мають досвід роботи в міжнародних організаціях або брали участь у різних багатосторонніх конференціях, явищем $є$ делегати, які не володіють жодною $з$ офіційних чи робочих мов, інколи взагалі соромляться брати слово, таким чином, значно зменшуючи внесок власної делегації й тим самим втрачаючи потенційну цінність досягнутого результату зустрічі.

Звичайно, будь-який дипломат та/чи фахівець з міжнародних відносин має вільний вибір використовувати будь-яку з мов, якою він може вільно вести комунікацію, особливо якщо він добре обізнаний у тому, якою мовною підготовкою володіє його співрозмовник. У деяких випадках для прийняття правильного рішення щодо використання мови потрібно вдаватися до 
дипломатичного підходу - інколи доцільним є зробити вибір на користь тієї мови, рівень володіння якої значно нижчий. Наприклад, фахівцю з міжнародних відносин та/або дипломатичної служби, який дуже добре спілкується на івриті, краще не використовувати цю мову у комунікаціях із арабським дипломатом. У той же час знаком доброї волі, ввічливості або особливої поваги буде привітання співрозмовника його рідною мовою. До цього прийому вдаються багато державних діячів та керівників дипломатичних делегацій, які здійснюють робочі візити в інші країни або беруть участь у міжнародних конференціях, тим самим висловлюючи свою повагу голові заходу або країні, в якій відбувається конференція (Mehtiyev, 2010).

Інший спосіб досягнення порозуміння у сфері міжнародних комунікацій полягає в бажанні однієї зі сторін-міжнародних акторів використовувати рідну мову свого партнера, що тим самим означає, що останній погоджується і готовий до деяких недоліків під час спілкування, оскільки ступінь іншомовної комунікаційної компетенції не завжди дорівнює рівню носія мови. Як носій мови людина може набагато краще усвідомлювати «приховані» конотативні значення і певні значення виразів, а в разі використання нерідної / іноземної мови вони можуть легко виходити із поля зору (Nick, 2001, p. 40).

Способом подолання мовних бар'єрів у міжнародних комунікаціях $€$ взаємне погодження на використання третьої мови, тобто мови-посередника, якою ніхто з учасників не володіє на рівні носія мови. Це, у свою чергу, призводить до ситуації, коли теоретично жодна зі сторін-учасниць міжнародної взаємодії не має несправедливої переваги щодо мовної компетенції. Звичайно, у випадку, якщо одна зі сторін (або обидві) не володіють мовою-посередником на достатньому рівні, це, у свою чергу, може призвести до ряду непорозумінь. Тим не менш, на сьогодні це один із поширених методів у практиці як міжнародного, так i дипломатичного спілкування, особливо в менш формальних випадках, таких як прийоми або інші заходи (Nick, 2001, p. 40).

Особливим способом вирішення питання використання різних мов $\epsilon$ застосування перекладачів, людей, які $є$ посередниками між комунікаторами. Це може відбувається в тих випадках, коли або учасники комунікативної ситуації не володіють спільною для обох сторін мовою, або вони навмисно не хочуть безпосередньо спілкуватися, використовуючи спільну мову. Згідно з дипломатичним протоколом, високопоставлені державні діячі, глави держав повинні використовувати свою рідну мову в певних офіційних випадках, а застосування перекладачів $\epsilon$ поширеною тактичною практикою дипломатичних перемовин.

\section{Висновки}

Таким чином, важливим напрямом професійної підготовки фахівців у сфері міжнародних відносин є їх підготовка до професійної кар'єри. Йдеться 
не тільки про «класичні» характеристики міжнародника (це фахівець високого класу, який досконало розуміється на всіх «тонкощах» принципів, особливостях зовнішньої політики своєї держави та інших країн, бути професіоналом у міжнародних справах, володіти рідною, англійською, мовою країни свого перебування, володіти ораторським мистецтвом, дипломатичним красномовством, мистецтвом еристики, діалогічним мовленням, мати добре сформовані риторичні вміння, уміти аналізувати інформацію; це державний службовець, який завжди діє у правовому полі, згідно з чинними законами та зовнішньополітичною доктриною держави, отриманих рекомендацій, міжнародного права; це фахівець, який глибоко розуміє цілі, завдання i особливості зовнішньополітичного курсу країни, яку він представляє, володіє високим рівнем політичної і громадянської свідомості), а й про здатність до стратегічного бачення розвитку подій, вміння передбачати наслідки дій, прогнозувати тенденцію розвитку ситуації, знання сучасних інформаційно-комунікаційних технологій, вміння використовувати ïх у повсякденній дипломатичній роботі; високий загальноосвітній і культурний рівень, толерантність тощо.

Професійна діяльність фахівців з міжнародних відносин, дипломатів, міжнародних акторів є сферою міжнародної комунікації, що включає політику, проблеми та події суспільного і державного життя. Виконання ними своїх професійних обов'язків вимагає сформованості знань щодо специфіки спілкування $з$ міжнародними партнерами, зокрема сформований системний комплекс компетенцій (лінгвістичної, комунікативної, аналітичної та лінгвокраїнознавчої), що уможливлює адекватне розуміння зарубіжних партнерів, послуговуючись як вербальними, так і невербальними засобами спілкування, які $\epsilon$ характерними для іншої культури.

Отже, фахівці з міжнародних відносин та працівники дипломатичної служби повинні вирізнятися уміннями і навичками конструювати професійний діалог з представниками інших культур і презентувати результати власної діяльності на міжнародному рівні, зокрема, за допомогою володіння іноземними мовами на рівні, що дає можливість здійснювати професійну діяльність, брати участь у міжнародних дискусіях 3 професійної проблематики 3 урахуванням контекстуальної значущості ситуації, особливостей мовної картини світу країни перебування, лінгвістичних та екстралінгвістичних факторів, що зумовлюють ведення переговорів.

\section{References:}

1. Diplomacy. The Oxford English Dictionary. Available at: https://www.oxfordlearnersdictionaries.com/definition/english/diplomacy?q=Diplo macy. 
Міжнародні відносини: теоретико-практичні аспекти

Випуск 6 (2020)

ISSN (print) 2616-745X; ISSN (online) 2616-7794

2. Kashchyshyn, N. (2017). 'Osoblyvosti dyplomatychnoi movy: istoriia i sohodennia' [Features of diplomatic language: history and present]. Everest, [online]. Available at: https://everest-center.com/osoblivosti-diplomatichnoyi-movi-istoriya-isogodennya/.

3. Mehtiyev, A. (2010). 'The language of diplomacy'. California Linguistic Notes, Volume XXXV, no. 2.

4. Nick, S. (2001). 'Use of Language in Diplomacy'. Language and Diplomacy. Malta: DiploProjects, pp. 39-48.

5. Vydy ta formy mizhnarodnykh vidnosyn (Types and forms of international relations), [online]. Available at: https://dist.karazin.ua/moodle/mod/page/view.php?id=70070.

(C) Білецька 0. О., 2020 